\title{
Menggugat \\ 'Pemikiran Konvensional' Pembangunan di Negara Berkembang
}

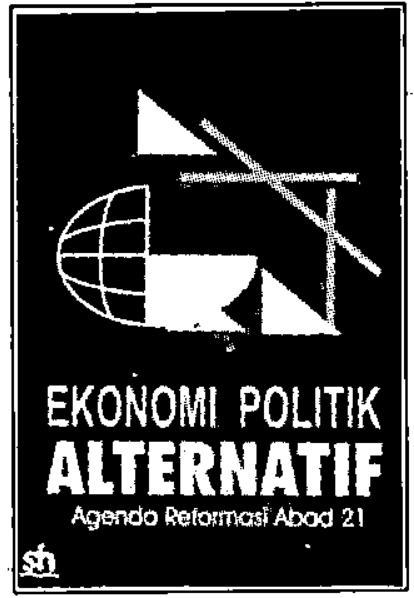

ergumulan pemikiran tentang kon- . sepsi pembangunan sebenarnya bukan hal yang baru. Ini dapat kita simak dari perjalanan panjang disdiskursus pembangunan yang kurang lebih sama dengan usia pembangunan itu sendiri. Pergulatan ini semakin menghangat ketika muncul anomali-anomali sebagai buah dari pembangunan itu sendiri, sehingga sampai sekarang dapat dikatakan belum ada suatu kerangka teori yang secara tuntas dan menyeluruh dapat digunakan sebagai panacea untuk mengatasi ketertinggalan negara berkembang. Terlebih dalam menembus dimensi ruang dan wak- tu, konsepsi pembangunan acapkali terasa kecapaian dan kedodoran untuk dapat menjelaskan fenomena yang terjadi.

Ketika muncul teori modernisasi, internal problem dari negara berkembang dikedepankan yang kemudian diikuti tawaran solusi berupa proses modernisasi. HarodDomar, Max Weber, David Mc-Clelland, W.W. Rostow, Bert F. Hoselitz, Alex Inkeles dan David H. Smith; para pendekar dari kelompok ini secara gigih menawarkan konsep pembangunan berupa 'replikasi" modernisasi yang terjadi di Barat (westernization). Teori ini pada akhirnya terpinggirkan karena replikasi pembangunan ala 
Barat ini cenderung mengabaikan perbedaan setting sosio-eko-kultural negara berkembang yang jelas-jelas berbeda dengan Barat.

Fase berikutnya muncul teori ketergantungan yang mencoba mengedepankan teori pembagian kerja internasional yang tidak fair sebagai penyebab hambatan pembangunan di negara berkembang. Dengan pendekatan dependensia, ditemukan adanya pola hubungan negara maju dan berkembang yang cenderung eksploitatif. Bukannya terjadi transfer dari yang 'si kuat' kepada 'si lemah', tetapi yang terjadi justru pengalihan surplus dari negara pinggiran ke negara pusat, sehingga negara pinggiran kehilangan sumber utama yang dibutuhkan untuk membangun negerinya. Meski teori ini kemudian gagal menjelaskan dinamika yang terjadi di negara pinggiran, tetapi teori ini memberi kontribusi yang tidak kecil dalam dialektika pembangunan dunia ketiga yang kemudian memunculkan teori-teori pembangunan pasca ketergantungan. Di antara teori-teori yang muncul tersebut ialah teori Liberal, teori Bill Warren, teori Artikulasi dan teori Sistem Dunia. (Arif Budiman, 1995)

Belum sempurna-untuk tidak mengatakan belum ada - teori pembangunan yang secara holistik bisa menjelaskan kemajuan serta paradoks -tidak jarang justru ini yang dominan-yang selalu mengikuti proses pembangunan itu sendiri, dapat dikatakan sebagai stimulus utama dari tulisan Didin S. Damanhuri.

Melalui setting pembangunan yang terjadi di Indonesia, penulis secara eklektik (electil) mencoba mensistensis serta mengkaji ulang esensi dari pembangunan itu sendiri. la tidak mau dikatakan sebagai seorang liberalis tetapi sekaligus tidak ingin dikategorikan sebagai penyanjung sosialis. Dengan menggunakan metode 'suka-suka', ia bersikap heterodoks; menyebal - meminjam istilah Dawam dalam pengantar buku ini- dari grand theory yang mapan. la tidak mau didikte oleh mainstream economy theory yang ada, meski pendekatan ini yang mendominasi khasanah pemikiran pembangunan saat ini. Hal ini dilakukan untuk menghindari perangkap analisis 'konvensional' yang seringkali tidak relevan serta tidak mampu menafsirkan paradoks pembangunan yang sering - atau bahkan selalu- muncul. Ketika suatu kerangka teori tertentu diaplikasikan sedangkan yang muncul adalah paradoksnya, maka penjelasan yang muncul seringkali cenderung bersifat apologi belaka.

Buah pikiran Didin yang 'nakal' untuk mencoba tidak tunduk kepada norma-norma pembangunan konvensional sangat kentara pada bagian pertama dari buku ini yang bertajuk "Tinjauan Masalah Dasar Teori dan Model Pembangunan serța Impli= kasinya." Pada bagian ini ia mengkritik habis kebiasaan para perencana pembangunan - dengan banyak mengambil Indonesia sebagai kajian- yang hanya bersifat sebagai konsumen teori yang mapan, tanpa ada keberanian untuk mencoba menguji keabsahan sebuah teori, apalagi mau mencoba memakai kerangka pemikiran di luar arus utama.

Dengan meng-agendakan model-model pembangunan yang telah binen (established), yang terdiri dari (1) model welfare state ala negara-negara Skandinavia (Swedia, Finlandia, Denmark) dan negara-negara di mana partai sosialis memerintah atau warna kemasyarakatannya mengadopsi aspirasi kaum sosial-demokrat seperti Perancis, Spanyol, Jerman dan Inggris (2) model negara kemakmuran ala Jepang (3) model populis ala negara-negara komunis, khususnya RRC pra reformasi (4) sistem neo liberalisme dengan regulasi sosial oleh kalangan swasta ala Reaganomic; Didin mengajak pembaca untuk merenungkan 
dan mengkaji ulang keampuhan modelmodel pembangunan yang telah dan akan diaplikasikan di negara-negara dunia ketiga - khususnya Indonesia - serta memikirkan "format alternatif" di masa depan. (hal. 32-40)

Menurut catatannya, selama masa orde baru pendekatan pembangunan yang dipakai lebih banyak diwarnai pendekatan pragmatik dibanding model sistematik dengan strategi yang matang.Realisasi pembangunan yang dapat dikatakan signifikan barulah solusi dalam mengurangi jumlah di bawah garis kemiskinan dengan sistem redistribusi lewat transfer dana secara langsung melalui peran dominan lembaga kepresidenan (terutama program-program Inpres); sementara fenomena timpangnya pembagian kue pembangunan tidaklah dapat dipandang masalah yang sederhana dan ringan. Sangat mungkin prosesnya menyangkut kebutuhan "institusionalisasi" yang sistematis dengan waktu yang lebih panjang dan kompleks, misalnya dalam hal pengembangan industri kecil, sektor informal, koperasi, perbankan sebagai agen pembangunan, sistem jaminan sosial, pengupahan minimum buruh, pengaruh anti-monopoli dan kartelisasi dan seterusnya dan seterusnya.

Berbagai implikasi negatif dari pembangunan -yang sangat mungkin uncontrolable dan unpredictable - secara lebih lengkap dan mendalam diungkap dalam bagian kedua dari buku ini. Berbagai persoalan yang menyangkut monopoli, kongIomerasi dan ekonomi rakyat, korupsi, keberadaan prinon pribumi, kesenjangan sosial. kemiskinan, eksistensi petani, sektor informal, serta problematika pasca suksesi sampai agenda yang harus disiapkan Indonesia untuk memasuki era globalisasi dicoba disajikan pada bagian ini.

Pekerjaan rumah berupa konsentrasi modal dan ketimpangan, telah menyeret pada kondisi yang kronis yang berujung pada penguasaan sekitar $60 \%$ dari PDB oleh 200-300 konglomerat. Sebagai akibat dari struktur pasar yang monopolis, oligopolis atau bahkan kartel membawa korban teralienasinya para pengusaha kecil dan menengah juga para pendekar ekonomi di sektor informal; padahal mereka yang dapat dikatakan sebagai pure entepreneur. Mereka semua terbiasa berada dalam pasar yang mendekati perfect competition dan berebut secara tajam tanpa mengharap fasilitas dan proteksi dari birokrasi -bahkan mereka cenderung akan disingkirkanhanya sayangnya kue yang mereka rebut proporsinya makin lama makin kecil. Sementara itu, para pengusaha besar yang sangat bergantung pada kekuasaan (client businessmen) terus mendapat fasilitas dan proteksi untuk berebut kue yang makin menggelembung dan sering harus menyingkirkan para wiraswastawan sejati. Berbagai paket kebijakan ternyata belum secara menyeluruh dapat memecahkan masalah, sehingga kondisi ini mendorong kebutuhan lahirnya strategi yang menyeluruh untuk menghadapinya, berupa "New Economic Policy".

Sebagai ending dari buku ini, Didin mengingatkan sekaligus menawarkan sebuah solusi. Menurut Didin, langkah strategis yang harus segera dilakukan adalah dekonstruksi terhadap epistemologi teoriteori pembangunan yang diadopsi selama ini. Akan sangat sulit bila kita ingin menjadikan ekonomi kerakyatan -yang berorientasi pada kesejahteraan dan keadilan sosial- sebagai wacana dominan dalam pembangunan, bila landasan epistemologi pembangunan Barat masih belum terdekonstruksi. Langkah ini kemudian diikuti dengan pembongkaran kembali tatanan praksis atas nama janji-janji kesejahteraan dari setiap bantuan dan kerja sama, baik dengan lembaga-lembaga internasional 
maupun dalam hubungan bilateral dengan negara-negara maju, meski bukan bersifat menutup diri dan anti globalisasi. Dalam perspektif inilah sangat penting untuk kembali membangkitkan wacana budaya nusantara yang dilandasi oleh tradisi budaya bangsa yang bersumber pada nilai-nilai agama (islam sebagai agama mayoritas) guna menangkal -menyaring lebih tepatnya- invasi budaya Barat. (hal 192-197)

Secara umum, buku ini menarik untuk dibaca, paling tidak sebagai alternatif dari wacana ekonomi pembangunan yang didominasi mainstreem economy theory yang terasa membosankan. Namun patut dicatat, buku ini merupakan kumpulan dari tulisan yang pernah dipublikasikan di ber- bagai media massa; sehingga harapan untuk mencerna alur pemikiran dan lontaran ide penulis dengan smoothly terasa susah didapat. Beberapa pengulangan pemikiran kerapkali muncul, sehingga terasa agak membosankan. Kelemahan lain dari buku ini adalah pemikiran-pemikiran 'alternatif' dari pembangunan yang ingin ditawarkan penulis terasa masih sangat hipotesis. $\mathrm{Pe}$ mikiran-pemikiran tersebut belum mampu terderifasi dan terformulasikan secara sistematis dalam suatu kerangka konseptual yang kokoh, jelas dan aplicable. Apalagi bila pemikiran-pemikiran tersebut dimaksudkan untuk 'menggoyang' pemikiran-pemikiran pembangunan yang telah ada dan eshtablish.

Arif Hartono

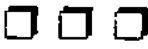

